\title{
Western Fisheries Research Center-Forage Fish Studies in Puget Sound
}

Researchers at the Western Fisheries Research Center are working with other U.S. Geological Survey (USGS) Centers to better understand the interconnected roles of forage fishes throughout the ecosystem of Puget Sound, Washington. Support for these studies primarily is from the USGS Coastal Habitats in Puget Sound (CHIPS) program, which supports studies of the nearshore areas of Puget Sound. Human perturbations in the nearshore area such as shoreline armoring or urban development can affect the nearshore habitats critical to forage fish.
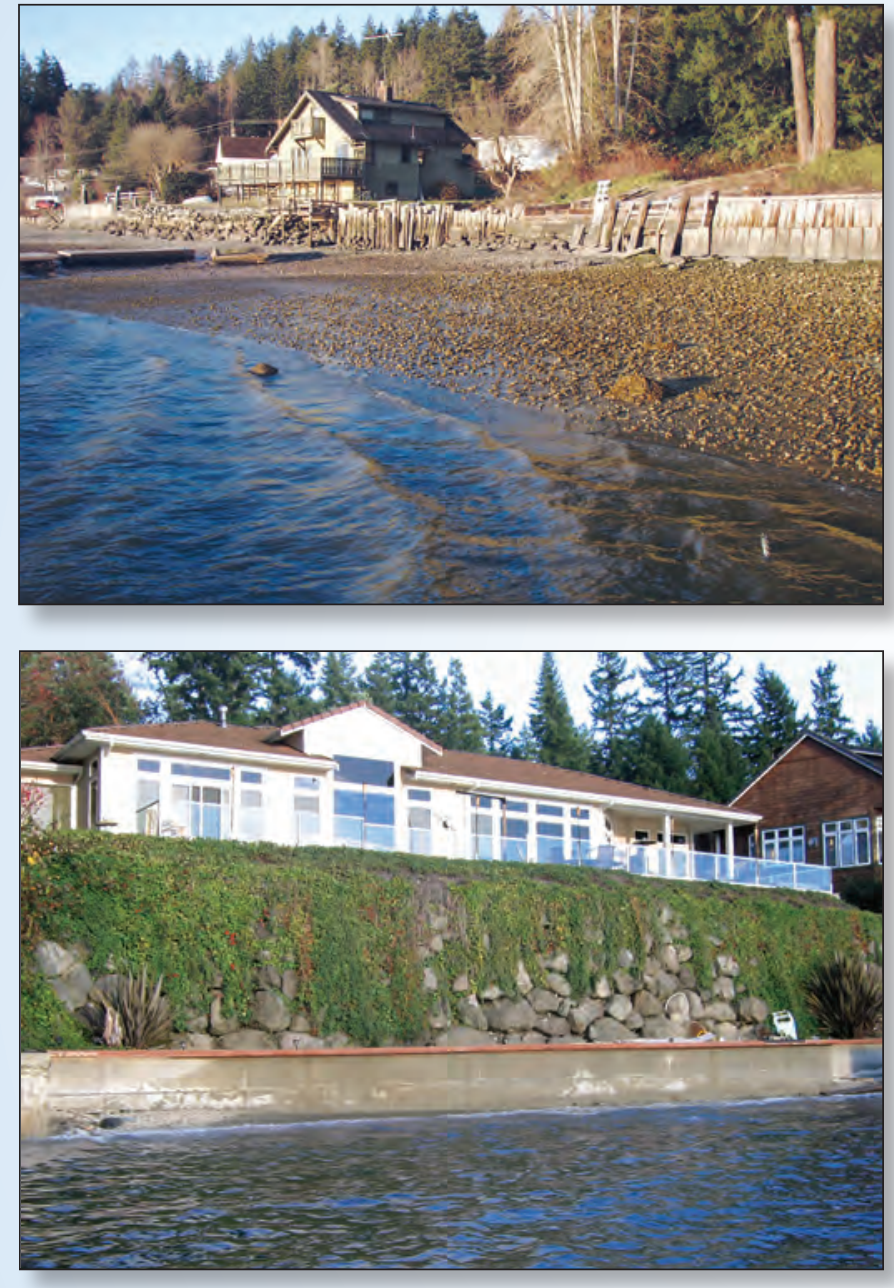

Negative effects of shoreline armoring include reduced beach width, accelerated sediment scour, and restricted beach nourishment.

\section{Urbanization of Puget Sound}

Puget Sound is the second largest estuary in the United States and has about 4,000 kilometers of shoreline. Approximately one-third of this shoreline has been armored. The projected growth of the region is expected to add as many as 1.4 million new residents by 2025 . Water quality, contaminants, and shoreline habitat modifications can affect a wide range of species in the ecosystem

\section{Why Forage Fish?}

The marine food web in Puget Sound relies on forage fish, which form the vital link between zooplankton and higher trophic levels such as birds, salmon, and killer whales. The forage fish assemblage in Puget Sound includes Pacific herring, surf smelt, Pacific sand lance, Pacific sardine, Pacific anchovy, and other species commonly referred to as "bait fish." The abundance trends of Pacific herring are estimated by stock assessment surveys, but little is known about the status of the other forage fish species. The population of Pacific herring spawning at Cherry Point, Washington, once the largest stock in Puget Sound, declined by about 90 percent between 1973 and 2000 . The reduced stock has affected the availability of food for higher trophic levels. For example, surf scoters, seabirds that consume herring eggs during their spring migration, showed a population decline that directly paralleled the decline of the herring stock.

\section{Beaches as Spawning Habitat}

USGS researchers studied beaches that are used as spawning habitat by surf smelt and Pacific sand lance in central Puget Sound (Liberty Bay, Washington) and determined that surf smelt spawned in winter on a sand-gravel substrate in the upper 10 meters of the beach. A predictive model is being developed to assist resource managers in forecasting critical spawning habitat for surf smelt.


Surf smelt 


\section{Forage Fish in the Food Web}

Puget Sound water currents called drift cells may determine where juvenile forage fish end up for rearing after dispersal. Juvenile surf smelt and Pacific sand lance may be transported from spawning beaches to nearby eelgrass beds for rearing. Most Pacific sand lance do not live past 2 years of age so reproduction and rearing are important to the survival of the species. A multidisciplinary team of USGS researchers is studying the reproduction and early life history to understand how populations of forage fish use the resources of the nearshore area. The research team uses a diverse set of tools such as hydroacoustic technology to map the distribution of eelgrass, acoustic Doppler current profilers to assess water currents, and dual-frequency identification sonar, an acoustic camera that can produce effective images without a light source, to monitor the distribution and behavior of forage fish.

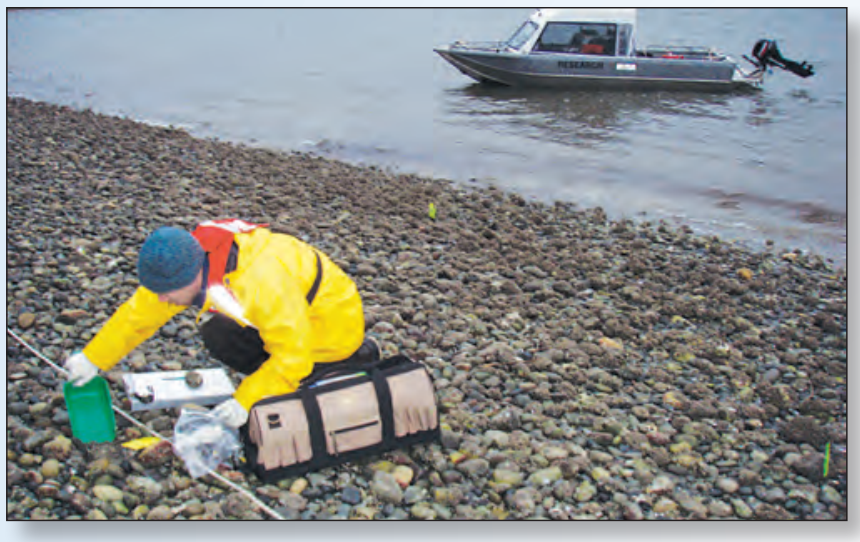

USGS researchers survey forage fish spawning to determine preferred spawning habitat.

\section{Science Impact}

\section{Sea Level Rise}

Urban communities are likely to respond to sea level rise with an increase in armoring to delay the natural erosion of shorelines. This response will "squeeze" forage fish spawning beaches between rising water levels and armoring structures. USGS researchers are using models to understand the effects the "squeeze" will have on fish that rely on beaches for their survival.

\section{Urban Development and Shoreline Armoring}

Puget Sound beaches are critical for surf smelt and Pacific sand lance spawning, but the effects of urbanization or shoreline armoring on forage fish survival are poorly understood. Models to simulate how forage fish use nearshore areas will be valuable to resource managers and planners in the future. The USGS is working with cooperators to understand better the basic life history requirements of forage fish and the genetic foundation of forage fish stocks.

Publishing support provided by the

U.S. Geological Survey

Tacoma Publishing Service Center

\section{Forage Fish Linkages to ESA-Listed Species}

Several fish, mammals, and birds of Puget Sound are listed under the Endangered Species Act (ESA). The threatened Chinook salmon, chum salmon, and bull trout all rely to some extent on healthy populations of forage fish. The marbled murrelet is a threatened seabird whose reproductive success has been linked with the availability of forage fish, specifically the Pacific sand lance. The USGS has established partnerships with tribes, the State of Washington, and other Federal agencies to support the recovery of listed species through an improved understanding of forage fish.

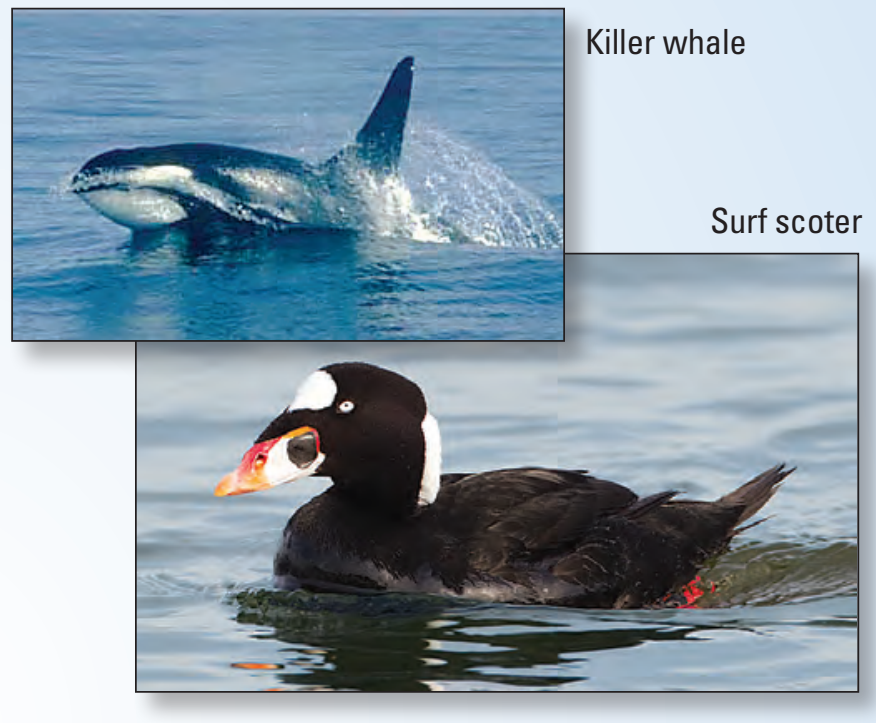

\section{Emerging Science}

- Food web dynamics involving forage fish (interactions with zooplankton and seabirds)

- Sea level rise and the potential to squeeze the shoreline habitats of Puget Sound

- Critical forage fish rearing and foraging habitats such as eelgrass

- Forage fish linkages to ESA-listed salmon, killer whale, Steller sea lion, and marbled murrelet

- Ongoing urbanization of the Puget Sound area and effects on nearshore habitats and restoration initiatives

- Effects of infectious and parasitic diseases on forage fish populations
Author: Theresa L. Liedtke

For Information Contact:

Director, Western Fisheries Research Center

U.S. Geological Survey

6505 NE 65th Street

Seattle, WA 98115

$\mathrm{Ph:}$ (206) 526-6282 FX: (206) 526-6654

http://wfrc.usgs.gov

Photograph credits: Surf scoter Axel Hildebrandt, Surf smelt

U.S. Geological Survey 